https://helda.helsinki.fi

On interpreters' working memory and executive control

\title{
Hiltunen, Sinikka
}

2016

Hiltunen , S , Pääkkönen , R , Vik , G-V \& Krause , C M 2016 , ' On interpreters' working memory and executive control ' , International Journal of Bilingualism, vol. 20 , no. 3 , pp. 297-314 . https://doi.org/10.1177/1367006914554406

http://hdl.handle.net/10138/163192

https://doi.org/10.1177/1367006914554406

acceptedVersion

Downloaded from Helda, University of Helsinki institutional repository.

This is an electronic reprint of the original article.

This reprint may differ from the original in pagination and typographic detail.

Please cite the original version. 


\section{On interpreters' working memory and executive control}

International Journal of Bilingualism

(C) The Author(s) 2014 Reprints and permissions: sagepub.co.uk/journalsPermissions.nav DOI: | $0.1|77 /| 3670069 \mid 4554406$ ljb.sagepub.com

(SAGE

\title{
Sinikka Hiltunen
}

Institute of Behavioral Sciences, University of Helsinki, Finland

\section{Rauni Pääkkönen}

Municipality of Sipoo, Finland

\section{Gun-Viol Vik}

Faculty of Philosophy, University of Vaasa, Finland

\section{Christina M. Krause}

Institute of Behavioral Sciences, University of Helsinki, Finland

\begin{abstract}
Research questions: The purpose of the study was to reveal new aspects of interpreters' memory and executive control.

Design: The memory and executive control of simultaneous and consecutive interpreters were compared to those of foreign language teachers and non-linguistic experts in two experiments: free recall and cocktail-party dichotic listening.

Data: Volunteers were 94 participants (22 to 26 participants in each group) with a minimum of 10 years of professional experience.

Findings: Simultaneous interpreters outperformed the non-linguistic experts in free recall. Though most of them detected their name in the cocktail-party test, they made no errors in the first and second word after it. In contrast, consecutive interpreters exceeded the performance of non-linguistic experts in seldom detecting their name in the cocktail-party test, as well as in making just a few errors in the first word after it. The results seem to indicate expertisedependent differences between the two interpreter groups, as well as between foreign language teachers and non-linguistic experts. For simultaneous interpreters, the findings can be explained by conditions at work which demand the continuous dividing of attention between listening to the source text, formulating and speaking the target text, and even monitoring and comparing the equivalence of the two. With consecutive interpreters, the results could reflect high demands for resisting external distractions at work.

Originality: The results seem to point to expertise-dependent differences in memory and executive control between different foreign language expert groups achieved as a result of thorough experience in their field of expertise.
\end{abstract}


Significance: In addition to the memory processes, executive control seems to play a significant role in explaining the cognitive processes of simultaneous and consecutive interpreting compared to that of other experts, both linguistic and non-linguistic.

\section{Keywords}

Free recall, executive control, cocktail-party dichotic listening, simultaneous interpreter, consecutive interpreter

\section{Introduction}

The main purpose of this article is to present some new aspects of interpreters' working memory and executive control. Executive control is generally considered a collection of interrelated abilities that enables people to modify their thoughts and actions. In other words, executive control allows people to pursue intentionally some thoughts and actions while inhibiting others (Baddeley, 1986; Schmeichel, 2007).

Executive control is also one of the functions of working memory. Oberauer, Süß, Wilhelm, and Wittman (2003), for instance, distinguish four main functions of memory: the simultaneous maintenance and processing of information in memory; the supervision of ongoing processes; and the coordination of elements into structures. The maintenance and processing of information are traditionally considered to be the main processes of working memory (Baddeley, 1986, 1997), and the supervision of ongoing processes corresponds to executive control.

According to Cowan (2001), working memory consists of two components: the focus of attention and the activated part of long-term memory. Any perception of stimuli activates some items in the long-term memory, but usually only some of them are focused. As the focus of attention moves from the first items activated to other items, the first items still remain active for a limited time span, usually from 20 to 30 seconds.

Short-term and long-term memory processes, executive control included, should be especially well developed and organized in experts (Chase \& Ericsson, 1981; Ericsson \& Kintsch, 1995). By definition, expert performance is 'consistently superior performance on a specified set of representative tasks for a domain' (Ericsson \& Lehmann, 1996, p. 277). Achieving an expert level of performance requires continuous deliberate practice. This includes, among others, the acquisition, application and organization of knowledge into specialized patterns for future use, as well as the continuous modification of patterns according to feed-back (Ericsson, Krampe, \& Tesch-Römer, 1993; Ericsson \& Lehmann, 1996).

At work, however, individuals often rely on well-entrenched methods rather than exploring new methods. Thus, deliberate practice is an effortful activity motivated by the goal of continuously improving one's performance (Ericsson \& Charness, 1994). In this way, expertise in any field can be refined on a proficiency scale from novice to journeyman, and further to expert and master, the last two characterizing the level of the best professionals in the field and even exceeding it (Chi, 2003, adapted from Hoffman, 1998).

Consequently, exceptional memory and executive control skills are one example of the superior performance of experts which cannot usually be captured by standard working memory tests, such as digit span or other serial recall tests, in which effects of prior knowledge are excluded by test design (Ericsson \& Delaney, 1999; Ericsson \& Williams, 2007). But if the test design corresponds to expert skills rehearsed at work, experts do outperform non-experts. For example, in the study by Cavallini, Cornoldi, and Vecchi (2009), architects excelled non-experts in visuo-spatial memory 
tests $^{1}$ and literary people (secondary and high school teachers in Italian and literature) in verbal tests. Conversely, architects performed worse than non-experts in verbal tests, as did literary people in visuo-spatial tests. The test design issue seems to apply to simultaneous interpreters as well.

There are numerous studies on the working-memory capacity of simultaneous interpreters, though with fairly mixed results (see Köpke \& Signorelli, 2012, for a review). For instance, in experiments by Christoffels, De Groot, and Kroll (2006), experienced simultaneous interpreters outperformed experienced foreign language teachers and interpreting students (novices) in reading span, word span and speech span tests. Later, in a reading span test, ${ }^{2}$ Signorelli, Haarmann, and Obler (2012) also found better reading span scores for professional simultaneous interpreters compared to two bilingual groups (older and younger) and a group of younger interpreters. In contrast, in experiments by Köpke and Nespoulous (2006), novice interpreters outperformed experienced interpreters in listening span and in free recall.

Many of these experiments measured the working memory of simultaneous interpreters with serial recall tests. This, however, seems to be one of the main reasons for contradictory results (Köpke \& Signorelli, 2012): compared to novices, experienced simultaneous interpreters are advantaged only in free recall allowing the output of items in any order, but not in serial recall. Another reason for the mixed results seems to be participant selection: only simultaneous interpreters with enough experience would show better memory span scores.

In previous research, the memory functions of simultaneous interpreters have usually been compared to foreign language teachers or other bilingual groups. We preferred to recruit still another group of interpreters: consecutive interpreters. To the best of our knowledge, there is no previous research on the memory functions of consecutive interpreters. Besides that, several differences can be seen in cognitive demands between these two groups of expert interpreters, the most interesting for our purposes being memory and executive control.

In simultaneous interpreting (SI) the lag between incoming source text and spoken target text is very short: 2-3 seconds or 4-5 words (Christoffels \& De Groot, 2004; Lee, 2002; Treisman, 1965). In contrast, in consecutive interpreting (CI) the target text is produced only after the speaker has paused or completed his or her utterance (Colin \& Morris, 1996; see also Pöchhacker, 2004, for more detail).

These two modes of interpreting set quite different demands on the interpreter's cognitive abilities, memory and executive control. In SI, the interpreter's attention is divided between several processes: listening to an incoming sequence of the speaker's utterance, transforming it into the target language and expressing it while listening to the next sequence, as well as monitoring these processes and avoiding mistakes and, in extreme cases, even trying to correct mistakes that have occurred (see e.g. Pöchhacker, 2004). All this takes place under an extreme time pressure, setting high demands on the interpreter's executive control.

In $\mathrm{CI}$, in contrast, the length of a speech sequence can vary from tens of seconds to minutes or tens of minutes (Phelan, 2001). Most often, CI involves memorizing and maintaining the message for a shorter or longer time. To support the memory functions, a consecutive interpreter usually takes notes in a type of symbol-based shorthand. So, in the first phase, his or her attention is focused only on listening to the source text and trying to capture its essential message while taking notes of the most important components of the message. In the second phase, the interpreter transfers the memorized message into the target language, using the notes as a support (see e.g. Gile, 1997; Wu \& Wang, 2009). Consequently, compared to SI, there is a higher demand on maintaining the message than on executive control itself.

As to test design, at the time of planning the present study we were unaware of the abovementioned analyses by Köpke and Signorelli, which were published much later (in 2012); nevertheless, we ended up using a free recall test. This was because interpreters work with the meanings 
of utterances, not with mere words (Seleskovitch, 1976), and a free recall test allows the use of different memory strategies, such as clustering the items (Bousfield \& Cohen, 1953, 1955).

Besides the possibility of using memory strategies, the free recall test chosen (Lehto, 1996) focused on the inhibition of internal distractions, which is one of the controlled search components of working memory as defined by Engle and his co-workers (Engle, Cantor, \& Carullo, 1992; Engle, Tuholski, Laughlin, \& Conway, 1999; Kane \& Engle, 2000; Unsworth \& Engle, 2007, 2006; Unsworth, Redick, Heitz, Broadway, \& Engle, 2009). These scholars concentrate on finding individual differences through comparing individuals with the highest scores in a memory test (high-spans) to those having the lowest scores (low-spans).

Research has made use of different tests: memory tests (e.g. digit span with serial recall, reading span, and free recall), and tests measuring executive control, such as the Stroop test (Kane \& Engle, 2003) and cocktail-party dichotic listening (see e.g. Table 4 in Unsworth \& Engle, 2007). ${ }^{3}$ Individual differences have been found in the cocktail-party dichotic listening, for instance: highspans do not detect their name on the to-be-ignored channel as often as low-spans, nor do they make as many mistakes in the first and second word after the name, thus showing an exceptional ability to resist external distractions (Conway, Cowan, \& Bunting, 2001).

In sum, individual differences are primarily revealed in two processes: active maintenance in primary memory ('focus of attention', Cowan, 2001) and controlled search from secondary memory ('activated part of long-term memory', Cowan, 2001). Controlled search means the cuedependent selection and retrieval of relevant information and the inhibition of irrelevant information, as well as of any internal or external distractions (Unsworth \& Engle, 2007).

As this was the first time the memory and executive control of both consecutive and simultaneous interpreters were studied and the cocktail-party dichotic listening test was applied to interpreters, our research was exploratory in nature, with no advance hypothesis.

\section{Materials and methods}

\section{Participants}

As control for our experiments, two groups of experts seemed appropriate: another group of foreign language experts and a group of experts occupied in other fields of society. The first control group consisted of foreign language teachers, as they have, at least in Finland, approximately the same level of education and experience in foreign language training as interpreters. The latter group (called non-linguistic experts) has not been using a foreign language as second language at a professional level; they are occupied in management and clerical work, manufacturing industries, health care, and education (see Table 1 for more details).

Thus, four groups of experts volunteered: three groups of foreign language experts and one group of non-linguistic experts $(n=24 ; 19$ female, five male). The three language expert groups were: simultaneous $(n=22$, all female $)$ and consecutive $(n=22 ; 20$ female, 2 male) interpreters, and foreign language teachers $(n=26 ; 25$ female, 1 male $)$. All participants were native speakers of Finnish or early bilinguals (Finnish learned before the age of five).

As no background inquiry could be found which would reveal if the participant was an expert (Chi, 2003), only two criteria for expertise were used: level of education (BA or equivalent as a minimum), and at least 10 years of experience in one's field of expertise (Ericsson \& Lehmann, 1996). Mean age of participants by group varied from 44.9 (SD 7.8) to 49.6 (SD 7.5) years and length of professional experience in years from 16.6 (SD 6.7) to 19.4 (SD 9.9) with no significant differences between the four groups as regards age $(F(3,93)=1.578, p=.200)$ or professional experience $(F(3,93)=0.345, p=.793)$. 
Table I. Participants. Mean age, educational level, field of occupation, and professional experience.

\begin{tabular}{|c|c|c|c|c|c|}
\hline Group & $N$ & $\begin{array}{l}\text { Mean age in years } \\
\text { (SD; range) }\end{array}$ & Education level & (Field of) occupation & $\begin{array}{l}\text { Mean professional } \\
\text { experience in } \\
\text { years (SD; range) }\end{array}$ \\
\hline $\begin{array}{l}\text { Simultaneous } \\
\text { interpreters }\end{array}$ & 22 & $48.0(7.6 ; 32-61)$ & $\begin{array}{l}\text { BA or equiv. (2) } \\
\text { MA (20) }\end{array}$ & $\begin{array}{l}\text { conference interpr. } \\
(17) \\
\text { court interpreter (I2) } \\
\text { interpr.in business } \\
\text { negotiations (I0) } \\
\text { community interpr. (9) } \\
\text { translator (II) } \\
\text { teacher (3) }\end{array}$ & $16.6(6.7 ; 5-35)$ \\
\hline $\begin{array}{l}\text { Consecutive } \\
\text { interpreters }\end{array}$ & 22 & $49.6(7.5 ; 28-63)$ & $\begin{array}{l}\text { BA or equiv. (9) } \\
\text { MA (I3) }\end{array}$ & $\begin{array}{l}\text { community interpreter } \\
(16) \\
\text { court interpreter (I3) } \\
\text { interpreter in business } \\
\text { negotiations (13) } \\
\text { conference interpreter } \\
(2) \\
\text { translator (6) } \\
\text { teacher (9) } \\
\text { personal assistant (2) }\end{array}$ & I $7.4(8.5 ; 3-30)$ \\
\hline $\begin{array}{l}\text { Foreign } \\
\text { language } \\
\text { teachers }\end{array}$ & 26 & $46.6(7.0 ; 33-59)$ & $\begin{array}{l}\text { BA or equiv. (I) } \\
\text { MA }(25)\end{array}$ & $\begin{array}{l}\text { foreign language } \\
\text { teacher }(26) \\
\text { headmaster ( } 2 \text { ) } \\
\text { researcher (I) }\end{array}$ & I $7.6(7.0 ; 8-32)$ \\
\hline $\begin{array}{l}\text { Non-linguistic } \\
\text { experts }\end{array}$ & 24 & $44.9(7.8 ; 26-57)$ & $\begin{array}{l}\text { BA or equiv.(19) } \\
\text { MA (5) }\end{array}$ & $\begin{array}{l}\text { administration and } \\
\text { clerical work (6) } \\
\text { manufacturing industry } \\
\text { and laboratory (9) } \\
\text { health care (2) } \\
\text { teaching (other than } \\
\text { languages) (4) } \\
\text { commerce (2) } \\
\text { culture (I) }\end{array}$ & $19.4(9.9 ; 3-40)$ \\
\hline
\end{tabular}

Finland being a small language area, most interpreters are employed in several different fields of work with foreign languages (see Table 1). It was therefore impossible to recruit enough volunteer interpreters with Finnish as their native language working exclusively in either simultaneous or consecutive mode. Consequently, the interpreter group was divided into two groups on the basis of the percentage of time used for interpreting in each mode, rated by the interpreters themselves: the interpreters working more simultaneously formed the SI group, and the interpreters working more in the consecutive mode the CI group. The mean interpreting time in the simultaneous mode of the SI group was $63.77 \%$ (range 20-100\%), and in the consecutive mode of the CI group $98.07 \%$ (range 91-100\%).

Most of the simultaneous interpreters worked as community and/or conference interpreters, while the consecutive interpreters worked mainly as community and/or court interpreters and/or interpreters in business negotiations. A few interpreters occasionally worked as teachers as well, 
but none of them full time. The foreign language teachers were employed as upper secondary school teachers or taught summer courses of the same level. Half of the teachers, as well as four of the non-linguistic experts, had interpreted occasionally in a school or family context (mostly in the consecutive mode), but none of them had any professional experience in interpreting.

To keep the control group as 'pure' as possible, participants with professional experience in the use of foreign languages or of native Finnish were excluded from the non-linguistic group. Also, to ensure that the non-linguistic expert group does differ from the linguistic expert groups, an extensive background questionnaire was filled in during the tests. This survey is not discussed in this article, but as an example, responses to three of the questions are shown in Table 2. Examples of the obvious differences found between the groups include the use of such expert skills at work as technical skills, craft-related skills, and skills in English. Such differences would indicate that the non-linguistic experts are not specialized in languages, not even in Finland's most common foreign language, English.

\section{Procedure}

The experiments took place in silent conditions in school or university buildings or at the interpreters' offices (community interpreting centres or the like) in the home regions of the participants (Helsinki, Tampere, Turku, Hämeenlinna, Hyvinkää, Vaasa, Oulu, plus a few smaller cities). Each participant was tested individually. The stimuli were presented through headphones from a CD player or MP3 player and the spoken answers were recorded with a laptop computer, using Cool Edit 2000.

The experiment procedure for free recall and dichotic listening tests (Experiments 1 and 2) is presented in Table 3. In the free recall, the participant was asked to carefully listen to the words presented in each block and to repeat them in any order at the end of block. The experiment session lasted about 55 minutes in all.

\section{Experiment I}

\section{Free recall tests}

Materials. For the free recall tests, two word lists were prepared, the first one with concrete and the second one with abstract nouns. Only the test with concrete words is reported in this article. The selected two- or three-syllable, five- to six-letter nouns were among the first 292 most common Finnish nouns in the Parole Corpus (Suomen kielen tekstipankki, 1996-1998) with a frequency of 793 to 8545 words per million. The concreteness of the words was rated by six independent native Finnish speakers on a scale of 1 to 10 , where $1=$ highly abstract (such as 'idea' or 'destiny') and 10 = highly concrete (such as 'elephant' or 'pencil'). 114 words were selected from the concrete end of the distribution. The concreteness of the words varied between 10 and 7.4 (mean 8.6, SD 0.66).

The 104 words selected were divided into 16 blocks of different sizes. The size of the blocks varied from 3 to 10 words, with two blocks of each size (two blocks of three words, two blocks of four words, etc.). Additionally, 10 words were used for practice in the beginning of the session. Previously, a similar free recall test with Finnish materials has been provided by Lehto (1996). The words were recorded on a computer in a noise-insulated room by a female voice at a rate of one word per second, with enough time after each block for the spoken recall.

Results. In this experiment, only the sum for all correctly recalled words (called the total word span by Lehto (1996)) from the maximum total (104 words) was calculated. The mean values of 
Table 2. Participants' self-judged use of technical skills, craft-related skills, and foreign language (English) at work (number of participants at different degrees of use).

\begin{tabular}{|c|c|c|c|c|}
\hline & Very frequently & Frequently & To some degree & None \\
\hline \multicolumn{5}{|l|}{ Use of technical skills } \\
\hline Simultaneous interpreters $(n=2 \mathrm{I})$ & 1 & 0 & 10 & 10 \\
\hline Consecutive interpreters $(n=20)$ & I & 4 & 8 & 7 \\
\hline Foreign language teachers $(n=19)$ & 0 & I & II & 7 \\
\hline Non-linguistic experts $(n=22)$ & 6 & 5 & 6 & 5 \\
\hline \multicolumn{5}{|l|}{ Use of crafts-related skills } \\
\hline Simultaneous interpreters $(n=2 \mathrm{I})$ & 0 & I & 3 & 17 \\
\hline Consecutive interpreters $(n=20)$ & 0 & I & 7 & 12 \\
\hline Foreign language teachers $(n=19)$ & 0 & 0 & 4 & 15 \\
\hline Non-linguistic experts $(n=22)$ & 3 & 3 & 6 & 10 \\
\hline \multicolumn{5}{|l|}{ Use of foreign language (English) ${ }^{\mathrm{a}}$} \\
\hline Simultaneous interpreters $(n=20)$ & 8 & 7 & 4 & 1 \\
\hline Consecutive interpreters $(n=2 \mid)$ & 15 & 2 & 3 & 1 \\
\hline Foreign language teachers $(n=19)$ & 13 & 2 & 1 & 3 \\
\hline Non-linguistic experts $(n=22)$ & 2 & 4 & 13 & 3 \\
\hline
\end{tabular}

${ }^{a}$ The working language of some interpreters and teachers was other than English.

Table 3. Experimental procedure during the test session: testing order and filling in forms for background information.

Practice free recall test with 10 words (Appendix A, Block Al)

Filling in an inquiry on personal beliefs regarding memory and attention capabilities

Experimental free recall test (Appendix A, Experiment $I$ ) ${ }^{\mathrm{a}}$

Filling in a form regarding memory strategies used in free recall test

Cocktail-party dichotic listening test ${ }^{\mathrm{a}}$

Filling in a form with questions about the participant's experience during the cocktail-party test ${ }^{\mathrm{a}}$

Filling in the Cloninger temperament inventory (TCl) (Cloninger, 1994)

Filling in an inquiry on personal beliefs regarding memory and attention capabilities

a Only the free recall and dichotic listening tests are reported in this paper.

correctly recalled words by group with significance values of between-group analyses are presented in Table 4.

A 4-between (group) univariate test was performed. The criterion for statistical significance was set at $p=.05$ for all subsequent analyses. The analysis results revealed a significant main effect of group $\left(F(3,88)=5.165, p<.003, \eta_{\mathrm{p}}{ }^{2}=.150\right)$. The Material $\times$ group interaction did not reach significance.

A Bonferroni adjusted between-group contrast analysis demonstrated that the significant difference was due to simultaneous interpreters outperforming the non-linguistic experts, with $p<.007$. There were no significant differences in free recall between the three linguistic expert groups or between consecutive interpreters and non-linguistic experts (see Table 4).

Errors in free recall. The results of the 4-between-group univariate test did not reveal any significant difference between the groups: $F(3,89)=1.586, p=.198, \eta_{\mathrm{p}}^{2}=.051$ (see Table 4). 
Table 4. Mean values for all correctly recalled concrete words and number of errors in the free recall test by group.

\begin{tabular}{|c|c|c|c|c|c|}
\hline \multirow[t]{3}{*}{ Stimuli } & \multirow{2}{*}{$\begin{array}{l}\text { Simultaneous } \\
\text { interpreters } \\
n=22 \\
\end{array}$} & \multirow{3}{*}{$\begin{array}{l}\text { Consecutive } \\
\text { interpreters } \\
n=22 \\
\text { Mean (SD) }\end{array}$} & \multirow{3}{*}{$\begin{array}{l}\begin{array}{l}\text { Foreign language } \\
\text { teachers }\end{array} \\
n=26 \\
\text { Mean (SD) }\end{array}$} & \multirow{3}{*}{$\begin{array}{l}\text { Non-linguistic } \\
\text { experts } \\
n=23 \\
\text { Mean (SD) }\end{array}$} & \multirow{3}{*}{$\begin{array}{l}\text { Total } \\
n=93 \\
\text { Mean (SD) }\end{array}$} \\
\hline & & & & & \\
\hline & Mean (SD) & & & & \\
\hline Concrete words & $0.79(0.08)$ & $0.76(0.08)$ & $0.77(0.07)$ & 0.71 (0.09) & $0.76(0.08)$ \\
\hline $\begin{array}{l}\text { ANOVA 4-between } \\
\text { (Bonferroni corrected } \\
\text { contrasts) }\end{array}$ & $(<.007)$ & $(=.189)$ & $(=.075)$ & & $<.02$ \\
\hline $\begin{array}{l}\text { Number of errors, } \\
\text { concrete words }\end{array}$ & $5.82(3.78)$ & 7.95 (4.09) & 6.31 (3.87) & $6.00(2.73)$ & 6.51 (3.69) \\
\hline
\end{tabular}

Following the classification of errors in free recall by Unsworth and Engle (2007), the errors were sorted into three types: previous list intrusions (PLI), extra list intrusions (ELI), and repetitions. The between-group differences for different error types could then be analysed using statistical methods; this revealed additional qualitative information on resistance to internal distractions. The observed frequencies, expected values, ${ }^{4}$ and post hoc cell contributions for error type are presented in Table 5.

A chi-square test was used to study the relationship between different expert groups and error types. The skill level of linguistic experts, especially interpreters, compared to non-linguistic experts affected the distribution of errors, $X^{2}(6, n=92)=14.480, p<.05$. The post hoc cell contributions at the level of $p<0.05$ showed that, compared to other groups, the non-linguistic experts made more PLI and ELI than expected. In contrast, simultaneous interpreters made fewer PLI and consecutive interpreters fewer ELI than expected. As to repetition errors, it was the interpreters, and especially the simultaneous interpreters, who made more errors than expected, while the nonlinguistic experts made fewer of them than expected. The performance of the foreign language teachers in avoiding errors was closer to the expected level than with the other groups, with one exception: they made more PLI than expected, but not as many as the non-linguistic experts.

\section{Discussion}

Simultaneous interpreters and foreign language teachers outperformed non-linguistic experts in the free recall. The results corroborate previous findings for expert memory skills in different fields, such as taxi drivers (Kalakoski \& Saariluoma, 2001), and architects and literature teachers (Cavallini et al., 2009), with experts outperforming novices when meaningful materials are presented. The current results are, however, not consistent with the findings of Christoffels \& De Groot (2004), for instance: in their study simultaneous interpreters were able to outperform foreign language teachers as well. Their tests, though, used serial recall and a visual presentation of words, which could explain the difference compared to our results.

Differences in executive control skills between the groups were found when errors were analysed by type. Both interpreter groups seem to be skilled in inhibiting internal interference, but each group excelled in different types of inhibition: simultaneous interpreters were better at inhibiting PLI, and consecutive interpreters at inhibiting ELI. In contrast, both interpreter groups, and especially simultaneous interpreters, seem to be prone to repetition errors. 
Table 5. Observed frequencies of errors, expected values, and post hoc cell contributions for tested groups by set of concrete words.

\begin{tabular}{|c|c|c|c|c|c|}
\hline \multirow[t]{2}{*}{ Error type } & \multicolumn{4}{|c|}{ Concrete words } & \multirow[t]{2}{*}{ Total } \\
\hline & $\begin{array}{l}\text { Simultaneous } \\
\text { interpreters }\end{array}$ & $\begin{array}{l}\text { Consecutive } \\
\text { interpreters }\end{array}$ & Teachers & $\begin{array}{l}\text { Non-linguistic } \\
\text { experts }\end{array}$ & \\
\hline \multicolumn{6}{|l|}{ Previous list intrusions } \\
\hline Observed frequency & 28 & 50 & 52 & 46 & 176 \\
\hline (Expected values) & 37.3 & 51.0 & 47.5 & 40.2 & \\
\hline Post hoc cell control & -9.3 & -1.0 & 4.5 & 5.8 & \\
\hline \multicolumn{6}{|l|}{ Extra list intrusions } \\
\hline Observed frequency & 49 & 64 & 66 & 63 & 242 \\
\hline (Expected values) & 51.3 & 70.1 & 65.3 & 55.3 & \\
\hline Post hoc cell control & -2.3 & -6.1 & .7 & 7.7 & \\
\hline \multicolumn{6}{|l|}{ Repetitions } \\
\hline Observed frequencies & 51 & 61 & 45 & 29 & 186 \\
\hline (Expected values) & 39.4 & 53.9 & 50.2 & 42.5 & \\
\hline Post hoc cell control & 11.6 & 7.1 & -5.2 & -13.5 & \\
\hline Totals & 128 & 175 & 163 & 138 & 604 \\
\hline
\end{tabular}

It seems thus that simultaneous interpreters are especially skilled in inhibiting irrelevant information and consecutive interpreters in inhibiting associations (phonological, semantic, or contextual) from entering into the focus of attention. This could possibly be explained by differences in the work processes. Through dividing their attention between several processes, simultaneous interpreters have become adept at focusing on relevant information: there is not enough capacity or time for anything else. As regards the consecutive mode, interpreters have to be accurate in finding equivalent words, and often no synonyms are allowed. This is especially true for community and court interpreting. However, as such a result has not been previously described, more research is necessary to explain the specificity in the inhibition of internal intrusions by interpreters working in different modes: SI or CI.

\section{Experiment 2: Dichotic listening (cocktail-party)}

\section{Materials}

To test the inhibition of (external) distractions, a modified version of dichotic listening (the 'cocktailparty test') (Conway et al., 2001; Moray, 1959) was used. Among the most common Finnish words in the Parole Corpus (Suomen kielen tekstipankki, 1996-1998), 510 five-letter words were selected and divided between two lists: 270 words for the to-be-attended (shadowed) word list and 240 words for the to-be-ignored list. The first list was recorded on a computer by a male voice and the second by a female voice in a monotonous tone at one word per 1.20 seconds. The volume of the female voice was technically lowered by $3 \mathrm{~dB}$ to make the voices more similar in perception. The two lists were synchronized into a stereo voice. The first 30 words $(0.36$ seconds $)$ were presented only on the to-be-repeated right-ear channel and were meant for shadowing practice. After this, both voices were presented in synchrony. As the 210th word (at 4.12 minutes) on the to-be-ignored list, the participant's own first name was recorded by the same female voice. Previously, the same test with Finnish words has been used by Pääkkönen in her Master's thesis (2009). 
Table 6. Detecting one's name (in \%) and errors in cocktail-party test by group.

\begin{tabular}{|c|c|c|c|c|c|}
\hline \multirow[t]{2}{*}{ Measure } & \multirow{2}{*}{$\begin{array}{l}\text { Simultaneous } \\
\text { interpreters }\end{array}$} & \multirow{2}{*}{$\begin{array}{l}\text { Consecutive } \\
\text { interpreters }\end{array}$} & \multirow{2}{*}{$\begin{array}{l}\text { Foreign language } \\
\text { teachers }\end{array}$} & \multirow{2}{*}{$\begin{array}{l}\text { Non-linguistic } \\
\text { experts }\end{array}$} & \multirow{2}{*}{$\begin{array}{l}\text { All } \\
\text { participants } \\
n=85^{a}\end{array}$} \\
\hline & & & & & \\
\hline \multicolumn{6}{|l|}{ Detecting one's name (\%) } \\
\hline Yes & 61.9 & 31.6 & 22.7 & 65.2 & 45.9 \\
\hline No & 38.1 & 68.4 & 77.3 & 34.8 & 54.1 \\
\hline \multicolumn{6}{|l|}{$\begin{array}{l}\text { Errors in dichotic } \\
\text { listening }\end{array}$} \\
\hline total (mean; SD) & $16.67(6.76)$ & $22.16(9.32)$ & $17.09(6.67)$ & $19.00(8.32)$ & $18.64(7.95)$ \\
\hline \multicolumn{6}{|l|}{ Errors: } \\
\hline -At hearing one's name & 0.85 & 0.89 & 1.00 & 1.00 & 0.94 \\
\hline -One word after the name & 0 & 0.05 & 0 & 0.39 & 0.11 \\
\hline -Two words after the name & 0 & 0 & 0 & 0.09 & 0.02 \\
\hline
\end{tabular}

${ }^{a} A$ few participants in the free recall test did not take part or failed to complete the test and were removed from the analyses.

bNumber of errors out of maximum possible by group.

\section{Participants and procedure}

Eighty-five of the same participants as for free recall tests took part the cocktail-party test, see Tables 1, 3 and 6 . The participant listened to the word list through headphones and was to shadow the words presented into the right ear and ignore the words on the left. The words repeated by the participant were recorded on the computer and, additionally, entered into a written protocol by the experimenter during the test.

After the test, the participants filled in a form with questions about their experience during the test. In addition to several distraction questions, the two most important questions were: 'Did you hear anything special on the to-be-ignored channel?' and 'Did you detect your own name on the to-be-ignored channel?'

\section{Results}

Two measures of the cocktail-party test were used: whether or not one's name was detected on the to-be-ignored channel and the number of shadowing errors in dichotic listening, especially those at or after the presentation of the participant's name. The results are presented in Table 6.

Of the 85 participants, almost half (45.9\%) detected their name on the to-be-ignored channel: $61.9 \%$ of the simultaneous interpreters, $31.6 \%$ of the consecutive interpreters, $22.7 \%$ of the teachers, and $65.2 \%$ of the non-linguistic experts. Since the participants could not be selected so that the length of their names was the same as the word-length (five to six letters), as in the experiment by Conway et al. (2001), an additional Pearson's chi-square test was performed. Detecting one's name on the to-be-ignored channel did not indicate any significant relation to the length of the name in letters $\left(X^{2}(4, n=85)=5.780, p=.225\right)$ or syllables $\left(X^{2}(4, n=85)=1.924, p=.867\right)$.

Almost all the participants (94\%) made an error in shadowing at the moment when their name was presented, regardless of whether they detected their name or not. Instead, in the first word after the name, only a few consecutive interpreters (5\%), and about a third of the non-linguistic experts $(39 \%)$ made an error. In the second word after the name, only some non-linguistic experts (9\%) made an error. In the third word after the name, no errors were made by any of the participants. 
As to the total number of errors in shadowing, the between-group differences did not reach significance $\left(F(3,81)=2.039, p=.115, \eta_{\mathrm{p}}{ }^{2}=.070\right)$ in the univariate test, nor did a chi-square test show any significant relation between detecting one's name and the number of errors in dichotic listening $\left(X^{2}(29, n=85)=36.169, p=.169\right)$.

A chi-square test was also performed to check for possible relations between the word span scores and detecting one's name on the to-be-ignored channel. No significant correlation was found for concrete words $\left(X^{2}(32, n=85)=32.779, p=.460\right)$.

\section{Discussion}

In the present study, a minority of foreign language teachers and consecutive interpreters $(22.7 \%$ and $31.6 \%$, respectively) detected their name on the to-be-ignored channel. The result is in good accordance with the results of equivalent experiments by Wood and Cowan (1995) and Conway et al. (2001). In their tests, $34.6 \%$ and 33\%, respectively, detected their name. However, the findings for simultaneous interpreters and non-linguistic experts did not correspond to the above-mentioned results: $61.9 \%$ of simultaneous interpreters and $65.2 \%$ of non-linguistic experts did detect their name in our test.

In the dichotic listening test, the only between-group error differences were found in errors in the first and second words following the participant's name (on the to-be-ignored channel). Simultaneous interpreters and foreign language teachers made no errors at these positions, and only a few errors were made by consecutive interpreters. In contrast, the number of errors by nonlinguistic experts was relatively high, $39 \%$ at the first and $9 \%$ at the second position. Thus, for the three linguistic expert groups in the test, the results do not support the findings by Conway et al. (2001): in their test $37.5 \%$ of the participants made an error in the first word and $30 \%$ in the second word after the name was presented. For possible explanations for these and other between-group differences, see 'General discussion'.

\section{General discussion}

When compared to non-linguistic experts, the results of the present study seem to indicate that simultaneous interpreters are superior in free recall and in dichotic listening. Though the majority of simultaneous interpreters did detect their name on the to-be-ignored channel in the cocktailparty test, they still made no errors in the first and second words after the name was presented, as non-linguistic experts did. Usually, high-spans, such as the simultaneous interpreters in our free recall test, do not detect their name as often as low-spans (Conway et al., 2001). Simultaneous interpreters are, however, accustomed to dividing their attention between two channels: listening to the incoming source text and to their own voice speaking the target text, and even comparing the two. Resorting to demanding executive control of this kind at work could explain why it is possible both to detect the name and avoid errors after hearing it.

The result is also in line with the results of Colflesh and Conway (2007). In their cocktail-party test, the participants were told before the test that their name would be presented on the to-beignored channel. Yet, only $66.7 \%$ of the high-span participants and $34.5 \%$ of the low-spans detected their name. According to Colflesh and Conway (2007), high-spans have a higher ability to control their focus of attention depending on task demands. This kind of superiority of executive control by simultaneous interpreters has previously also been shown in the Wisconsin card sorting task (WCST) by Yudes, Macizo, and Bajo (2011), in which simultaneous interpreters outperformed both bilinguals and monolinguals. In contrast, consecutive interpreters exceeded the performance 
of non-linguistic experts only in not noticing their name in the cocktail-party test and making only a few shadowing errors after its presentation.

As to the rest of the results, they could perhaps be explained in the light of an article by Friedman and Miyake (2004), which proposes three different executive control functions for inhibition and interference: prepotent response inhibition, resistance to distractor interference and resistance to proactive inhibition. Of these three functions, the resistance to distractor interference would seem to be different for simultaneous and consecutive interpreters at work. Thanks to interpreting booths with a high-quality noise insulation (ISO Standard 2603:1998, and 4043:1998), the need to resist distractor interference is almost non-existent for simultaneous conference interpreters. In contrast, CI takes place under totally different conditions: in meeting rooms with often quite loud air conditioning or in noisy factory buildings or workshops, sometimes even disrupted by telephones or incoming visitors. Consequently, consecutive interpreters are accustomed to resisting all external distractions at their work. This was also the case in our tests: they were good at resisting distractions from the to-be-ignored channel, including their own name.

As for foreign language teachers, they outperformed non-linguistic experts in free recall and most of them did not detect their name in the cocktail-party test, nor did they make errors after its presentation. These findings are consistent with those by Conway et al. (2001) and Wood and Cowan (1995), mentioned above. However, they also could be explained by the teachers' working conditions at school. Finnish upper secondary schools follow national core curricula, which set out the goals for each seven- to eight-week teaching period. Thus, the teachers have to concentrate on teaching and completing their plans for each lesson to the letter. Consequently, they cannot respond to all attempts by the students to attract the teachers' attention or to other distractions in class.

The present study seems to confirm that foreign language experts have special memory and executive control skills compared to non-linguistic experts. Such special skills could also be explained by bilingualism (or multilingualism) itself. Recent research has revealed, for instance, that in the bilingual brain, the words of both languages are activated when listening to one of the languages, but the irrelevant one has to be ignored (see e.g. Lagrou, 2012). Bilinguals may also be better at monitoring competing information, i.e. at selecting relevant information and inhibiting irrelevant information (Study IV by Soveri, 2013). This fact could obviously enhance memory.

However, as the test results differed in some respects for each of the linguistic expert groups, depending on what skills are extensively trained during education and at work, expertise seems to play an essential role in the memory and executive control of interpreters. This is in line with previous research on experts outperforming non-experts, when the test design corresponds to the skills exercised and refined at work (see e.g. Cavallini et al., 2009; Kalakoski \& Saariluoma, 2001).

\section{Summary and topics of future research}

Simultaneous interpreters and foreign language teachers outperformed non-linguistic experts in free recall (when tested in their native language). These findings could be explained by the demand for excellent memory at work for both simultaneous interpreters and foreign language teachers.

Foreign language teachers and consecutive interpreters did not detect their name on the to-beignored channel in the cocktail-party dichotic listening test to the same degree that simultaneous interpreters and non-linguistic experts did. This might be explained by the working conditions of teachers at schools and consecutive interpreters in noisy meeting rooms, demanding the strict inhibition of any external distractions.

Many questions, however, remain to be resolved by future research, especially what test design could reveal the possible differences in memory and executive control (cf. Friedman \& Miyake, 
2004) between consecutive and simultaneous interpreters in even greater detail than was possible in the present study.

\section{Acknowledgements}

The authors would like to thank the heads of their various institutions and organizations, as well as all colleagues and students, and, above all, the volunteer participants who contributed to this study. We are especially grateful to: Dr Lassi Liikkanen; Mari Laine, MA; laboratory engineer Kalevi Reinikainen; as well as Jari Lipsanen, MA; and Dr. Erkki Komulainen for their collaboration in the preparation and conducting of experiments, and performing statistical analyses. We also thank Drs. Virpi Kalakoski and Markku Ojanen, as well as Heli Mäntyranta, M.Phil., for insightful comments on and corrections to the manuscript.

\section{Funding}

This research received no specific grant from any funding agency in the public, commercial, or not-for-profit sectors.

\section{Notes}

1. Several visuo-spatial and verbal tests were administered both to architects and literature experts, such as: the Corsi Block Test, where the participants are required to reproduce sequences of spatial positions of cubes (visuo-spatial test), and digit span, where the participants are required to recall a sequence of digits or letters (verbal test), both presented on the screen.

2. In the reading span test, the participant has to read individual sentences and after the test to recall the last word of each sentence in serial order. In another version, each sentence has a single arbitrary word at the end, and these words have to be recalled after the test in serial order.

3. In the Stroop test, words denoting colours are presented, printed either in the same colour as the meaning of the word or in a contradicting colour. After the test, the correct words have to be recalled in serial order. The number of errors would indicate the ability of the participant to resist contradicting information.

4. The expected values in this statistical analysis indicates the difference compared to the number of errors if the errors had been distributed evenly between the groups.

\section{Reference}

Baddeley, A.D. (1986). Working memory, Oxford, UK: Clarendon Press.

Baddeley, A.D. (1990). Human Memory. Theory and Practise, Revised Edition (1997), Hove, UK: Psychology Press.

Bousfield, W.A., \& Cohen, B.H. (1953). The effects of reinforcement on the occurrence of clustering in the recall of randomly arranged associates, Journal of Psychology, 36, 67-81.

Bousfield, W.A., \& Cohen, B.H. (1955). The occurrence of clustering in the recall of randomly arranged words of different frequencies-of-usage, Journal of General Psychology, 52, 83-95.

Cavallini, E., Cornoldi, C., \& Vecchi, T. (2009). The effects of age and professional expertise on working memory performance, Applied Cognitive Psychology, 23, 382-395.

Chase, W.G., \& Ericsson, K.A. (1981). Skilled memory. In J.R. Anderson (Ed.), Cognitive skills and their acquisition (pp. 141-189). Hillsdale, NJ: Erlbaum.

Chi, M.T.H. (2003). Two approaches to the study of expert's characteristics. In K.A. Ericsson, N. Charness, P.J. Feltovich, \& R.R. Hoffman (Eds.), The Cambridge Handbook Of Expertise And Expert Performance (pp. 21-30). Cambridge, UK: Cambridge University Press.

Cloninger, C.R., Przybeck, T.R., Svrakic, D.M., \& Wetzel, R.D. (1994). The temperament and character inventory (TCI): a guide to its development and use, Washington University, Center for psychobiology of Personality, St. Louis. 
Christoffels, I.K., \& De Groot, A.M.B. (2004). Components of simultaneous interpreting: Comparing interpreting with shadowing and paraphrasing, Bilingualism: Language and Cognition, 7(3), 227-240.

Christoffels, I.K., De Groot, A.M.B., \& Kroll, J.F. (2006). Memory and language skills in simultaneous interpreters: The role of expertise and language proficiency, Journal of Memory and Language, 54, 324-345.

Colflesch, G.J.H., \& Conway, A.R.A. (2007). Individual differences in working memory capacity and divided attention in dichotic listening, Psychonomic Bulletin \& Review, 14(4), 699-703.

Colin, J., \& Morris, R. (1996). Interpreters and the Legal Process. Winchester, UK: Waterside Press.

Conway, A.R.A., Cowan, N., \& Bunting, M.F. (2001). The cocktail party phenomenon revisited: The importance of working memory capacity, Psychonomic Bulletin \& Review, 8(2), 331-335.

Cowan, N. (2001). The magical number 4 in short-term memory: A reconsideration of mental storage capacity, Behavioral and Brain Sciences, 24(1), 87-114.

Engle, R.W., Cantor, J., \& Carullo, J.J. (1992). Individual differences in working memory and comprehension: A test of four hypotheses. Journal of Experimental Psychology: Learning, Memory, and Cognition, 18(5), 972-992.

Engle, R.W., Tuholski, S.W., Laughlin, J.E., \& Conway, A.R.A. (1999). Working memory, short-term memory and general fluid intelligence: A latent variable approach. Journal of Experimental Psychology: General, 128, 209-331.

Ericsson, K.A., \& Charness, N. (1994). Expert performance. Its structure and acquisition, American Psychologist, 49(8), 725-747.

Ericsson, K.A., \& Delaney, P.F. (1999). Long-term Working Memory as an alternative to capacity models of working memory in everyday skilled performance, In A. Miyake, \& P. Shah (Eds.), Models of Working Memory. Mechanisms of Active Maintenance and Executive Control (pp. 257-297). Cambridge, UK: University Press.

Ericsson, K. A., \& Kintsch, W. (1995). Long-term working memory, Psychological Review, 102(2), 211-245.

Ericsson, K.A., \& Lehmann, A.C. (1996). Expert and exceptional performance: evidence of maximal adaptation to task constraints. Annual Revue of Psychology, 47, 273-305.

Ericsson, K.A., Krampe, R.Th., \& Tesch-Römer, C. (1993). The role of deliberate practice in the acquisition of expert performance, Psychological Review, 100(3), 361-406.

Ericsson, K.A., \& Williams, A.M. (2007). Capturing naturally occurring superior performance in the laboratory: Translational research on expert performance, Journal of Experimental Psychology: Applied, 13(3), 115-123.

Friedman, N.P., \& Miyake, A. (2004). The relations among inhibition and interference control functions: a latent-variable analysis, Journal of Experimental Psychology: General, 131(1), 101-135.

Gile, D. (1997). Conference interpreting as a cognitive management problem, In J. H. Danks, G. M. Shreve, S. B. Fountain, \& M. K. McBeath (Eds.), Cognitive Processes in Translation and Interpreting (pp. 196-214). Thousand Oaks, CA: Sage Publications.

Hoffman, R.R. (1998). How can expertise be defined? Implications of research from cognitive psychology. In R. Williams, W. Faulkner, \& J. Fleck (Eds.), Exploring expertise (pp. 81-100), New York, NY: Macmillan.

Kalakoski, V., \& Saariluoma, P. (2001). Taxi drivers' exceptional memory of street names. Memory \& Cognition, 29(4), 634-638.

Kane, M.J., \& Engle, R.W. (2000). Working-memory capacity, proactive interference, and divided attention: Limits on long-term memory retrieval, Journal of Experimental Psychology: Learning, Memory, and Cognition, 26(2), 336-358.

Kane, M.J., \& Engle, R.W. (2003). Working-memory capacity and the control of attention: The contributions of goal neglect, response competition, and task set to Stroop interference, Journal of Experimental Psychology: General, 132(1), 47-70.

Köpke, B., \& Nespoulous, J. (2006). Working memory in expert and novice interpreters, Interpreting, 8(1), $1-23$.

Köpke, B., \& Signorelli, T.M. (2012). Methodological aspects of working memory assessment in simultaneous interpreters, International Journal of Bilingualism, 16(2), 198-212. 
Lagrou, E. (2012). Auditory word recognition by bilinguals, Universiteit Gent, Faculteit Psychologie en Pedagogische Wetenschappen.

Lee, T.-H. (2002). Ear voice span in English into Korean simultaneous interpretation, Méta: journal des traducteurs / Méta: Translators' Journal, 47(4), 596-606.

Lehto, J. (1996). Are executive function tests dependent on working memory capacity? The Quarterly Journal Of Experimental Psychology, 49A(1), 29-50.

Moray, M. (1959). Attention in dichotic listening: Affective cues and the influence of instructions, Quarterly Journal of Experimental Psychology, 11, 56-60.

Oberauer, K., Süß, H.-M., Wilhelm, O., \& Wittman, W.W. (2003). The multiple faces of working memory: Storage, processing, and coordination, Intelligence, 31, 167-193.

Pääkkönen, R. (2009). Musiikin kuvittelun ei-tahdonalainen aktivoituminen ja työmuisti. Helsingin yliopisto, pro gradu -tutkielma (Helsinki University, Master Thesis).

Phelan, M. (2001). The Interpreter's Resource. Clevedon, UK: Multilingual Matters.

Pöchhacker, F. (2004). Introducing Interpreting Studies, London, UK: Routledge.

Schmeichel, B.J. (2007). Attention control, memory updating, and emotion regulation temporarily reduce the capacity for executive control. Journal of Experimental Psychology: General, 136(2), 241-255.

Seleskovitch, D. (1976). Interpretation: A psychological approach to translating. In R.W. Brislin (Ed.), Translation: Applications and Research (pp. 92-166). New York, NY: Gardner Press.

Signorelli, T.M., Haarmann, H.J., \& Obler, L.K. (2012). Working memory in simultaneous interpreters: Effects of task and age, International Journal of Bilingualism, 16(2), 198-212.

Soveri, A., (2013). Training executive functions in the laboratory and in real life: Cognitive consequences of computer-based exercises and bilingualism. Doctoral dissertation, Abo Akademi University Psychology Department of Psychology and Logopedics, Åbo, Finland: CorttiPrint.

Suomen kielen tekstipankki, versio A (suomen PAROLE-korpus). Suomen 1990-luvun yleiskielen digitaalinen tutkimusaineisto. EU:n LE-PAROLE-hankkeessa koostaneet Helsingin yliopiston yleisen kielitieteen laitos ja Kotimaisten kielten tutkimuskeskus, 1996-1998.

Treisman, A.M. (1965). The effects of redundancy and familiarity on translating and repeating back a foreign and a native language, British Journal of Psychology, 56, 369-379.

Unsworth, N., \& Engle, R.W. (2006). Simple and complex memory spans and their relation to fluid abilities: Evidence from list-length effects, Journal of Memory and Language, 54, 68-80.

Unsworth, N., \& Engle, R.W. (2007). The nature of individual differences in working memory capacity: Active maintenance in primary memory and controlled search from secondary memory, Psychological Review, 14(1), 104-132.

Unsworth, N., Redick, T.S., Heitz, R.P., Broadway, J.M., \& Engle, R.W. (2009). Complex working memory span tasks and higher-order cognition: A latent-variable analysis of the relationship between processing and storage, Memory, 17(6), 635-654.

Wood, N. L., \& Cowan, N. (1995). The cocktail-party phenomenon revisited: attention and memory in the classic selective listening procedure of Cherry. Journal of Experimental Psychology, 124(3), $243-262$.

Wu, G., \& Wang, K. (2009). Consecutive Interpretation: A Discourse Approach. Towards a Revision of Gile's Effort Model, Méta: journal des traducteurs / Méta: Translators' Journal, 54(3), 401-416.

Yudes, C., Macizo, P., \& Bajo, T. (2011). The influence of expertise in simultaneous interpreting on non-verbal executive processes, Frontiers in Psychology, 309(2), 1-9, http://www.frontiersin.org/ Psychology,05/07/2013.

\section{Author biographies}

Sinikka Hiltunen has M.A. degrees both in translation and interpreting (Tampere University) and in cognitive science (Helsinki University). For two decades, she worked as translator and consecutive interpreter, mainly for manufacturing industries. She is also an authorized translator. She is currently a doctoral student in 
Helsinki University and also works for various educational organizations as free-lance lecturer, educator and trainer on topics related to linguistics, psychology, and cognitive sciences.

Rauni Pääkkönen has M.A. degrees in computer sciences (Helsinki University of Technology) and in psychology (Helsinki University). She was employed by the Helsinki University of Technology while working on her M.A. thesis and later as researcher, and then as data analyst at the Finnish National Institute for Health and Welfare, participating in research projects on the epidemiology of chronic diseases. She currently works as school psychologist for the Sipoo local authority.

Gun-Viol Vik, PhD, associate professor at University of Vaasa, Department of Scandinavian Languages. Research interests are expertise in interpreting, professional language and communication, as well as bi- and multilingual practice in organizations. She works also as professional conference interpreter.

Christina M. Krause is Professor emerita in cognitive science, and specialist in human cognitive neuroscience, especially memory. Her publications comprise 51 full articles in international peer-reviewed international scientific journals. She has M.A. and PhD degrees in psychology (Åbo Akademi University). She has worked at Åbo Akademi University, University of Turku, Helsinki University of Technology and at University of Helsinki. Since the early 1990s she has been the principal investigator in tens of research projects. 


\section{Appendix A}

\section{Abstract word stimuli}

\section{Practice session}
tytär
marssi
velka
ikkuna
neste
kirje
avain
leipä
kissa
hopea

Experiment 1 (divided into 16 blocks of 3 to 10 words each, $n=104$ words):

$\begin{array}{llll}\text { Block 1 } & \text { Block 7 } & \text { Block 11 } & \text { Block 14 } \\ \text { virhe } & \text { juhla } & \text { muutos } & \text { riski } \\ \text { osuus } & \text { laatu } & \text { osasto } & \text { herra } \\ \text { laitos } & \text { tauko } & \text { ajatus } & \text { siirto } \\ \text { Block 2 } & \text { suosio } & \text { lääni } & \text { mieli } \\ \text { pituus } & \text { hanke } & \text { tahto } & \text { seikka } \\ \text { yhtymä } & \text { seura } & \text { vaihe } & \text { pääsy } \\ \text { kerta } & \text { Block } 8 & \text { tulos } & \text { tunne } \\ \text { Block 3 } & \text { sarja } & \text { valta } & \text { summa } \\ \text { sääntö } & \text { rouva } & \text { Block 12 } & \text { puolue } \\ \text { vapaus } & \text { teoria } & \text { huume } & \text { Block 15 } \\ \text { nopeus } & \text { tuotto } & \text { sanoma } & \text { tarve } \\ \text { kurssi } & \text { linja } & \text { vuoro } & \text { kokous } \\ \text { Block 4 } & \text { vaara } & \text { tuonti } & \text { puoli } \\ \text { yhtiö } & \text { Block } 9 & \text { totuus } & \text { arvio } \\ \text { tiede } & \text { yhteys } & \text { hetki } & \text { jäsen } \\ \text { etelä } & \text { elämä } & \text { talous } & \text { pelko } \\ \text { hahmo } & \text { sielu } & \text { näyttö } & \text { kasvu } \\ \text { Block 5 } & \text { viesti } & \text { Block 13 } & \text { länsi } \\ \text { käyttö } & \text { tapaus } & \text { vastuu } & \text { esitys } \\ \text { kansa } & \text { jakso } & \text { taide } & \text { asenne } \\ \text { tonni } & \text { tieto } & \text { toive } & \text { Block 16 } \\ \text { piiri } & \text { Block 10 } & \text { piirre } & \text { turva } \\ \text { keino } & \text { nousu } & \text { versio } & \text { huhde } \\ \text { Block 6 } & \text { oikeus } & \text { hoito } & \text { rikos } \\ \text { muoto } & \text { seutu } & \text { vietti } & \text { toivo } \\ \text { tappio } & \text { rooli } & \text { jatko } & \text { kiire } \\ \text { maine } & \text { voitto } & \text { rauha } \\ \text { kanta } & \text { säätiö } & & \text { väite } \\ \text { mitta } & \text { taito } & \text { virka } \\ & & \text { suunta } \\ \text { voima }\end{array}$




\section{Appendix B}

\section{Concrete word stimuli}

\section{Practice session:}

\section{Block A1}

tytär

marssi

velka

ikkuna

neste

kirje

avain

leipä

kissa

hopea

Experiment 1 (divided into 16 blocks of 3 to 10 words each, $n=104$ words):

$\begin{array}{llll}\text { Block 1 } & \text { Block 7 } & \text { Block 11 } & \text { Block 14 } \\ \text { tanssi } & \text { kortti } & \text { koira } & \text { pallo } \\ \text { jälki } & \text { tavara } & \text { paperi } & \text { kippo } \\ \text { lohko } & \text { puisto } & \text { maito } & \text { lista } \\ \text { Block 2 } & \text { kruunu } & \text { katto } & \text { järvi } \\ \text { lapsi } & \text { kieli } & \text { pöytä } & \text { piano } \\ \text { korko } & \text { kirkko } & \text { silmä } & \text { marja } \\ \text { mitali } & \text { Block } 8 & \text { markka } & \text { poika } \\ \text { Block 3 } & \text { sisko } & \text { aalto } & \text { sentti } \\ \text { metsä } & \text { pankki } & \text { Block 12 } & \text { johto } \\ \text { pinta } & \text { pommi } & \text { ystävä } & \text { Block 15 } \\ \text { kenkä } & \text { lehti } & \text { soitin } & \text { selkä } \\ \text { virta } & \text { perhe } & \text { lasku } & \text { asukas } \\ \text { Block 4 } & \text { talvi } & \text { tähti } & \text { merkki } \\ \text { vuokra } & \text { Block } 9 & \text { pappi } & \text { koulu } \\ \text { nainen } & \text { laiva } & \text { tontti } & \text { tukka } \\ \text { eläin } & \text { hirvi } & \text { ruoka } & \text { salmi } \\ \text { kuutio } & \text { teksti } & \text { kulta } & \text { osoite } \\ \text { Block 5 } & \text { palkka } & \text { Block 13 } & \text { tyttö } \\ \text { myyjä } & \text { koivut } & \text { kevät } & \text { lukko } \\ \text { piispa } & \text { seinä } & \text { lippu } & \text { sorsa } \\ \text { lukio } & \text { viini } & \text { polvi } & \text { Block 16 } \\ \text { kuusi } & \text { Block 10 } & \text { halli } & \text { linna } \\ \text { tauti } & \text { sauna } & \text { nurmi } & \text { kirja } \\ \text { Block 6 } & \text { risti } & \text { maali } & \text { lähde } \\ \text { maksu } & \text { tehdas } & \text { vaimo } & \text { kotka } \\ \text { syksy } & \text { ranta } & \text { viina } & \text { seppä } \\ \text { jalka } & \text { helmi } & \text { lintu } & \text { kauppa } \\ \text { museo } & \text { huone } & & \text { kenttä } \\ \text { penni } & \text { tammi } & & \text { litra } \\ & & \text { silta } \\ \text { emäntä }\end{array}$

